\title{
Which Retail Firm Characteristics Impact On Financial Distress?
}

\author{
Elok Heniwati ${ }^{*}$, Erlina Essen ${ }^{2}$ \\ 1,2Accounting Department, Universitas Tanjungpura \\ Л. Prof. Dr. H. Hadari Nawawi, Pontianak 78124, Indonesia \\ *Corresponding author; Email: 1*elok.heniwati@ekonomi.untan.ac.id; 2erlinaessen@gmail.com
}

\begin{abstract}
This study is to examine whether liquidity, profitability, leverage, sales growth, operating capacity, and size have influenced on financial distress by using retail industry that listed in the Indonesia Capital Market. Sample determination basing on purposive sampling results 19 companies with complete data over the observation period (2014-2018). Data was manually collected from the website, www.idx.com. By using logistic regression, the findings show that profitability and leverage have significant influenced on financial distress. Moreover, predictor liquidity, sales growth, operating capacity and firm's size have no relationship with financial distress.
\end{abstract}

Keywords: Liquidity; profitability; leverage; sales growth; operating capacity; firm size; financial distress.

\section{INTRODUCTION}

A sluggish stream of retail businesses in Indonesia, since 2017, has impacted on the decreasing of fast-moving consumer goods (FMCG) levels. As of September 2017, FMGC only grew 2.7 percent or equivalent to Rp12 trillion, while the average annual normal growth reached 11 percent. It means that there has been a loss of sales of Rp37 trillion (www.republika.com). A number of retail businesses have closed their outlets in several locations due to the decline in public purchasing power accompanied with the change of lifestyle and patterns of public spending. Customers prefer to choose online to the offline transaction since various e-commerce and marketplaces offer products at lower prices than that of conventional markets. The changes in consumption patterns have affected the sluggish incomes of retail businesses that generally rely solely on sales from physical stores. It has led to the closure of retail store such as the Seven Eleven on June 2017, and the performance decrease of other retail stores such as Matahari Department Store, which has closed several outlets during 2017-2018, Ramayana, Lotus, Debenhams, Dorothy Perkins, GAP and Banana Republic (2018) and the most recently is the Hero and Central Supermarkets at the beginning of 2019 (cnbcindonesia.com).

The facts situation above indicates that the firms experience financial difficulties or financial distress due to a decrease in profit. [24] argue that financial distress is a stage of financial decline before bankruptcy or liquidation. It begins with a decline in the company's ability to generate profits from its operations [29] signaled with a negative operating profit or net profit. Accumulation of negative net income can, in turn, cause the negative book value of a company's equity or equity deficien$\mathrm{cy}$, thus signaling negative information to investors [29]. It means that comparison among those financial ratios such as liquidity, profitability, leverage, and sales growth will provide reliable signals in predicting financial distress of firms [29].

Previous prominent studies have used financial ratios to predict corporate failures [1], [3], [4], [24], [34]. The work of [1] called Z-score models, which incorporates financial ratios, is mostly used to predict corporate financial distress [34]. It is believed that the Z-score provides a sound objective measure of financial distress as it emphasizes the insolvency risk [9], [28]. While [26] describes how financial ratios were used to credit analysis and managerial analysis, [1] and [3] use the financial ratios to predict the risk of company failures. The evidence suggested strongly that financial ratios could be reasonably efficient predictors of a variety of financial difficulties. More recently studies conducted in some countries such as Malaysia [12], [27], European Countries [8], [34], United Stated [31], India [30] found that financial ratios indicators could determine the financial health of a company.

There are numerous studies concerning factors influence on financial distress in Indonesia such as sales growth, liquidity, leverage, profitability, operating capacity and size [2], [6], [7], [14], [15], [16], [17], [18], [21], [22], [23], [32], [33]. However, despite the fact that numerous works of literature have examined the relationship between financial ratios and corporate failures, few pieces of literature specifically focused on the retail industry [18], [19]. Their 
studies found that the use of accounting variables can easily predict the bankruptcy. This paper is intended to limit the gap by using data from Indonesia, provided the country has been experiencing a sluggish stream of retail businesses since 2017. The objective is to assess determinant factors influencing the financial distress of the retail industry in Indonesia by using logistic regression. It is believed that this approach is favorable in terms of the statistical issue [8] and beneficial to examine all possibilities that occur on the dependent variable predicted by a set of predictors [11].

The remainder of the paper is organized as follows: the next section includes the literature review and hypothesis development. After explaining the research methodology, it deals with empirical findings and discussions. Finally, the conclusions are presented at the end of the passage.

\section{Hypothesis Development}

The framework of this study is developed based on the signaling theory [24] and agency theory [10]. It is believed that asymmetric information occurs in the labor market; thus, setting up a signal criterion to increase the strength of decision-making is essential [24]. In other words, signaling theory explains how a company signals to users of financial statements by providing information that management has done to fulfill the requirement of the principal. It mainly discusses market price volatility that affects investors' decisions and analysis of firm performance, signaling to the company's management. The information generated by the financial statements provides a positive signal (i.e., company success) and a negative signal (i.e., the potential for company failure through the low value of liquidity, profitability, and sales growth).

Furthermore, agency theory, which involves two related parties (agent and principal) doing business, deals with the separation of ownership and management between them [8]. The separation relationship might cause information asymmetry since the agent as a party running a business has potentially concealed the firm is going concern, essential information to the principal, as a party delegating some decision making authority to the agent. The agent tends to hide the firm condition during financial distress. Thus, analyzing the firm's financial statement through financial ratios such as leverage, liquidity, profitability, asset turnover, firm's size, sales growth, might disclose the firm's financial difficulty.

\section{Liquidity}

Liquidity is one of the vital information for investors in making decisions. The higher value of the current ratio indicates that there are excess current assets or cash (idle cash), meaning that companies cannot correctly manage it, thus causing less profitability. Conversely, the low value of the current ratio shows that the company has less capital to pay its short-term debt, meaning that companies experience lacking financial health (financial distress), which provides a bad signal to investors and eventually delaying their decision to invest in the company. Study of [2] [33] found that liquidity has a negative affect on financial distress, that is, the higher the level of liquidity of a company, the lower the possibility of the company experiencing financial difficulties. Thus, the hypothesis of the study is:

$\mathrm{H}_{1}$ : Liquidity negatively relates to financial distress.

\section{Profitability}

Return on investment (ROI) is one of the financial ratios to represent the firm's profitability, that is, to measure a firm's performance from assets perspective or the ability of assets to generate net profits. The higher value of ROI suggested that the company has optimally used its resources, thus resulting in high profits. In contrast, the lower value of ROI suggested that the company is less effective and efficient in asset utilization that might lead to financial distress. Profitability is essential information for investors as a basis to analyze the company's development in profit-making. The higher level of the company's profitability will give a positive signal to investors, meaning that they will have a positive return from their investments. Previous studies [17], [31], [33] found that profitability ratio is negatively influenced by financial distress. Thus, the hypothesis of the study is:

$\mathrm{H}_{2}$ : Profitability negatively relates to financial distress.

\section{Leverage}

The leverage or solvency ratio is generally used to measure how much debt finances the company's assets. The level of the ratio constitutes the firm's policy, and it becomes a signal for investors. It also represents the responsibility of the firm by providing information to stakeholders for decisionmaking. Generally speaking, a company with higher capital composition than debt could be categorized as healthy. Otherwise, it will be categorized as a company with financial distress. [6], [14], [31] found that leverage relates positively to financial distress. Thus, the hypothesis of this study is: $\mathrm{H}_{3}$ : Leverage positively relates to financial distress.

\section{Sales Growth}

Growth illustrates the company's ability to maintain its economic position amid economic 
growth and business competition. This research uses the ratio of increase in sales or sales growth measured by net sales of a company. Figuring the sales growth out might provide good news to management and investors because it can predict how much profit will be generated. Companies with low income generating are likely to experience financial distress, whereas high income generating might attract investors due to their ability to generate high profits. Study of [6], [32] found that the ratio of sales growth has a negative effect on financial distress. An increase in sales means that the company has increased profits, where this condition keeps the company away from potential financial distress. Thus, the hypothesis of this study is:

$\mathrm{H}_{4}$ : Sales growth positively relates to financial distress.

\section{Operating Capacity}

Operating capacity or activity ratio reflects the level of efficiency and effectiveness of the company's operational activities [16]. It assesses the company's ability to carry out daily activities. The higher the company's asset turnover rate indicates that the company has efficiently used its assets in generating sales revenue. It means that companies' management attempts to maximize their performance to reduce financial distress. Companies with unproductive sales, thus less in generating income, will tend to experience financial difficulties due to a lack of asset turnover. If companies could effectively and efficiently manage their assets, they will receive a short-term return, which usually can be calculated by total asset turnover [14], [32]. Low total asset turnover indicates that companies cannot effectively and efficiently manage their assets in their operational activities, thus resulting in low performance, and eventually leading to financial distress. $\mathrm{H}_{5}$ : Operating Capacity negatively relates to financial distress.

\section{Firm Size}

This study measures company size using the Natural Logarithm (Ln) of total assets considering that in addition to reflecting the firm's size, they affect the timeliness. The use of total assets is essential to reduce data fluctuations that might occur when using total sales [33]. The greater size of a company reflected by assets indicates that it has sufficient capital to carry out its operational activities. Further, the company could continue to innovate new products to attract the market or do a business expansion. Study of [23], [33] found that the large size of the company could minimize the possibility of the company being in a state of financial distress. Thus, the hypothesis of this study is:

$\mathrm{H}_{6}$ : Firm size negatively relates to financial distress.

\section{RESEARCH METHOD}

There are 28 retail companies listed in the Indonesia Capital Market for 2014-2018. All population meet the criteria to sample selection during the observation period, that is: (a) IPO before 2014; (b) not delisting; (c) relisting; (d) not move to other sectors; (e) have a full set of data. Data is manually collected from the IDX website, that is, www.idx. co.id.

For hypothesis testing purposes, this study uses financial ratios representing liquidity, sales growth, profitability, leverage, operating capacity, and company size as independent variables. Table 1 presents the measurement of the variables.

Table 1 Variable Measurement

\begin{tabular}{llc}
\hline Variable & \multicolumn{1}{c}{ Measurement } & Expected sign \\
\hline LIKU & Current ratio $=\frac{\text { Current Assets }}{\text { Current Liabilities }}$ & $(-)$ \\
PROF & ROI $=\frac{\text { Earning After Tax }}{\text { Total Assets }}$ \\
LEVE & DER $=\frac{\text { Total Debt }}{\text { Total Equity }}$ \\
PPEN & Sales growth $=\frac{\text { Sales }^{\mathrm{t}}-\text { Sales }^{\mathrm{t}-1}}{\text { Sales }^{\mathrm{t}-1}}$ \\
KAPO & Total asset turnover $=\frac{\text { Sales }_{\text {Total Assets }}^{(-)}}{\text {UKUR }}$ & LnTotalAsset
\end{tabular}

Note: LIKU = likuiditas (liquidity); PROF = profitabilitas (profitability); $\mathrm{LEVE}=$ leverage; KAPO = kapasitas operasional (operating capacity); $\mathrm{PPEN}=$ pertumbuhan penjualan (sales growth); UKUR = ukuran perusahaan (company size)

Dependent variable (financial distress) is measured by using [2] model, that is:

$$
\text { Altman ZScore }=6,56 T_{1}+3,26 T_{2}+6,72 T_{3}+1,05 T_{4}
$$

where $T_{1}, T_{2}$, and $T_{3}$ are net working capital, net income, and EBIT respectively, which is each one of them divided by total asset, and $\mathrm{T}_{4}$ is market value to equity divided by book value to liability. The result will be categorized into companies with ZScore more than 2.9 and companies with Z-Score less than 2.9. Further, the dummy variable is calculated, a company with Z-Score $>2.9$ is valued 1 , and a company with Z-Score $<2.9$ is valued 0 .

Data analysis for this study is descriptive statistics to provide general information about the mean, range, standard deviation, minimum, and maximum of data. In addition, classical assumption test (multicollinearity and autocorrelation), logistic regression and hypothesis test (coefficient determination $\left[R^{2}\right]$ based on the Nagelkarke $R$ Square value, model fit [F-test] based on Hosmer and Lemeshow's Goodness of Fit Test value, overall model fit based on -2Log likelihood function, and $t$ test). 
The model for structural logistic regression equation is as follows:

$$
L n=\frac{F D}{1-F D}=a+B_{1} \mathrm{LIKU}+B_{2} \mathrm{PROF}+B_{3} \mathrm{LEVE}+B_{4} \mathrm{PPEN}+
$$

Where;

$$
\begin{array}{ll}
\text { FD } & =\text { financial distress, } \\
\text { LIKU } & =\text { liquidity, } \\
\text { PROF } & =\text { profitability } \\
\text { LEVE } & =\text { leverage, } \\
\text { PPEN } & =\text { sales growth, } \\
\text { KAPO } & =\text { operating capacity, } \\
\text { UKUR } & =\text { company size, } \\
\text { a } & =\text { constant } \\
\text { B } & =\text { coefficient }, \text { and } \\
e & =\text { error term. }
\end{array}
$$

\section{RESULTS AND DISCUSSION}

Prediction of the financial distress of sample companies using the Altman Z-score model shows that there is 56 (58.9\%) companies experience financial distress, and $39(41,1 \%)$ companies that are categorized far from financial distress.

Table 2. Descriptive Statistics

\begin{tabular}{lcrrrrr}
\hline & N & \multicolumn{1}{c}{ Range } & \multicolumn{1}{c}{ Min } & \multicolumn{1}{c}{ Max } & \multicolumn{1}{c}{ Mean } & Std. Dev. \\
\hline LIKU & 95 & 14.0173 & 0.0127 & 14.0300 & 2.5903 & 2.9617 \\
PROF & 95 & 12.0090 & -10.8894 & 1.1197 & -0.2313 & 1.4840 \\
LEVE & 95 & 12.2934 & -4.9933 & 7.3001 & 1.2477 & 1.7191 \\
PPEN & 95 & 132.1327 & -1.0000 & 131.1327 & 1.6545 & 13.5930 \\
KAPO & 95 & 19.5428 & 0.8821 & 20.4249 & 2.0258 & 2.5649 \\
UKUR & 95 & 8.0604 & 22.6692 & 30.7296 & 28.4567 & 1.6493 \\
\hline
\end{tabular}

Note: LIKU=likuiditas (liquidity) [current assets/current liabilities]); $\mathrm{PROF}=$ profitabilitas (profitability) [earnings after tax/total assets (ROI)]; LEVE=leverage [total debt/ total equity (DER)]; KAPO=kapasitas operasional (operating capacity) [sales/total assets (TATO)]; PPEN=pertumbuhan penjualan (sales growth) [(salest-sales $\left.{ }^{\mathrm{t}-1}\right) /$ sales $\left.^{\mathrm{t}-1}\right)$ ]; UKUR=ukuran perusahaan (company size) [natural logarithm of total assets].

Moreover, Table 2 presents descriptive statistics for predictor variables. It can be seen that the range of current ratio (LIKU) is 14,0173 ranging from minimum (0.0127-PT Rimo International Lestari Tbk, 2014) to maximum (14.0300-PT Electronic City Indonesia Tbk, 2015) with standard deviation 2.9617. The mean value is 2.5903 , denoting that, on average, the sample industries can guarantee Rp1 of current liability with Rp2.59 of current assets. The range of profitability ratio (PROF) is 12.0090 ranging from minimum (10.8994-PT Trikomsel Oke, Tbk, 2015) to maximum (1.1197-PT Skybee Tbk, 2016) with standard deviation 1.4840 . The mean value is -0.2313 , denoting that, on average, the sample industries can generate a return for $\mathrm{Rp} 0.23$ from $\mathrm{Rp} 1$ of assets. The range of debt to equity ratio (LEVE) is 12.2934 ranging from minimum (-4.9933-PT Skybee, Tbk, 2015) to maximum (7.3001-PT Kokoh Inti Arebama Tbk, 2018) with standard deviation 1.7191.
The mean value is 1.2477 , denoting that, on average, the sample industries can settle $\mathrm{Rp} 1$ of debt with Rp1.25 of capital. The range of sales growth ratio (PPEN) is 132.1327 ranging from minimum (1.0000-PT Skybee Tbk, 2015) to maximum (131.1327-PT Rimo International Lestari Tbk, 2016) with standard deviation 13.5930 . The mean value is 1.6545 , denoting that, on average, the sample industries experience with sales growth for 1.65 times. The range of total asset turnover ratio (KAPO) is 19.5428 ranging from minimum (0.8821-PT Electronic City Tbk, 2016) to maximum (20.4249-PT Global Teleshop Tbk, 2015) with standard deviation 2.5649 . The mean value is 2.0258, denoting that, on average, the sample industries experience with asset turnover for 2.03 times. The range of company size (UKUR) is 8.0604 ranging from minimum (22.6692-PT Rimo International Lestari Tbk, 2014) to maximum (30.7296-PT Sumber Alfaria Trijaya Tbk, 2018) with standard deviation 1.6493. The mean value is 28.4567, denoting that, on average, the sample industries have a total asset for Rp28.47.

The results of classical assumption tests show that research data is free from multicollinearity and autocorrelation symptoms. All predictor variables have the value of Tolerance that less than 0.10 and the value of VIF that more than 0.05 . Furthermore, autocorrelation test using Run Test method shoes that the value of Asymp. Sig. (2-tailed) is more than $0.05(0,122>.05)$. It means that the model regression has no autocorrelation problem.

\section{Logistic Regression Analysis Results}

Table 3 presents the results of logistic regression. The equation developed from the model is as follows:

$$
\begin{aligned}
L n=\frac{F D}{1-F D}= & -10.290+0.070 \mathrm{LIKU}-22.629 \mathrm{PROF}+1.542 \mathrm{LEVE} \\
& -0.112 \mathrm{PPEN}+0.554 \mathrm{KAPO}+0.232 \mathrm{UKUR}+e
\end{aligned}
$$

The constant value of equation is -10.290 , meaning that if the value of variable LIKU, PROF, LEVE, PPEN, KAPO, and UKUR is 0, the value of the Altman z-score of retail industry is -10.290 times.

Based on the Nagelkerke $R$ Square value, the coefficient determination of the equation is 0.746 . It means that the independent variables could explain the variability of the dependent variable as much as $74.6 \%$. Other variables explain the remaining variability (25.4\%) do not include in the equation. Further, the result of the Hosmer and Lemeshow's Goodness of Fit Test shows that the value of significance is more than $0.05(0.689>0.5)$. It means that $\mathrm{H}_{0}$ is accepted, and the model could predict the observation value, or the model could be accepted since it fits with its data observation. 
Table 3. Relationship between Financial Ratios and Financial Distress

\begin{tabular}{lrrrrrr}
\hline & \multicolumn{1}{c}{ B } & S.E. & Wald & df & Sig. & Exp(B) \\
\hline LIKU & .070 & .165 & .180 & 1 & .672 & 1.072 \\
PROF & -22.629 & 9.766 & 5.369 & 1 & .020 & .000 \\
LEVE & 1.542 & .404 & 14.584 & 1 & .000 & 4.675 \\
PPEN & -.112 & .214 & .274 & 1 & .600 & .894 \\
KAPO & .554 & .612 & .821 & 1 & .365 & 1.741 \\
UKUR & .232 & .335 & .480 & 1 & .489 & 1.261 \\
Constant & -10.290 & 9.490 & 1.176 & 1 & .278 & .000 \\
Negelkerke R Square & 0.746 \\
F-statistics & \multicolumn{5}{c}{$5.624(.689)$} \\
Observation & 95 & \\
\hline
\end{tabular}

Table 4. Overall Model Fit Step One

\begin{tabular}{rrrr}
\hline \multirow{2}{*}{ Iteration } & \multirow{2}{*}{-2 Log likelihood } & Coefficients \\
\cline { 3 - 3 } Step 0 & 1 & 128.640 & Constant \\
& 2 & 128.639 & -.358 \\
3 & 128.639 & -.362 \\
\hline
\end{tabular}

Table 5. Overall Model Fit Step Two

\begin{tabular}{|c|c|c|c|c|c|c|c|c|c|}
\hline \multirow{4}{*}{\multicolumn{2}{|c|}{ Iteration }} & \multirow{4}{*}{$\begin{array}{c}-2 \mathrm{Log} \\
\text { likelihood }\end{array}$} & \multicolumn{7}{|c|}{ Coefficients } \\
\hline & & & \multirow{3}{*}{ Constant } & \multirow{3}{*}{$\begin{array}{c}\text { Current } \\
\text { Ratio }\end{array}$} & \multirow{2}{*}{$\begin{array}{c}\text { Return } \\
\text { On }\end{array}$} & \multicolumn{2}{|l|}{ Debt } & \multirow{3}{*}{$\begin{array}{c}\text { Total } \\
\text { Asset } \\
\text { Turnover }\end{array}$} & \multirow{3}{*}{$\begin{array}{l}\text { Ln } \\
\text { Total } \\
\text { Asset }\end{array}$} \\
\hline & & & & & & $\mathrm{T}_{0}$ & Sales & & \\
\hline & & & & & Investment & Equity & Growth & & \\
\hline Step & 1 & 96.199 & 5.843 &. .109 & .308 & .471 & .001 & .110 & .239 \\
\hline \multirow[t]{10}{*}{1} & 2 & 86.995 & 6.145 & -137 & -.806 & .677 & $\cdot .009$ & .277 & .270 \\
\hline & 3 & 64.471 & 1.010 & .007 & -4.843 & .914 & -.042 & .312 & -.114 \\
\hline & 4 & 56.468 & -3.628 & .020 & -8.191 & 1.288 & -.058 & .489 & .015 \\
\hline & 5 & 54.089 & -6.953 & .049 & -11.461 & 1.461 & -.078 & .565 & .115 \\
\hline & 6 & 52.639 & -8.939 & .068 & -15.897 & 1.496 & -.099 & .553 & 183 \\
\hline & 7 & 52.065 & -9.795 & .068 & -20.552 & 1.524 & -103 & .535 & .216 \\
\hline & 8 & 52.015 & -10.253 & .070 & .22 .423 & 1.540 & -111 & .550 & .231 \\
\hline & 9 & 52.014 & -10.289 & .070 & -22.627 & 1.542 & -112 & .554 & .232 \\
\hline & 10 & 52.014 & -10.290 & .070 & .22 .629 & 1.542 & -.112 & .554 & .232 \\
\hline & 11 & 52.014 & -10.290 & .070 & .22 .629 & 1.542 & -.112 & .554 & .232 \\
\hline
\end{tabular}

The overall model fit is conducted in two steps. The first step results (see Table 4) a 128.639 of - $2 L o g$ Likelihood, and this value is more than 0.05, meaning that the $\mathrm{H}_{1}$ is accepted; that is, the hypothesized model does not fit with the data before incorporating independent variables into the regression model. Then, the second step overall model fit was conducted to examine and compare the first value of $-2 \mathrm{Log}$ Likelihood (block number 0) to the second value of 2Log Likelihood (block number 1) (see Table 5). It can be seen that the second value of $-2 \log$ Likelihood is 52.014, decreasing for 76.625 (128.63953.014), meaning that adding independent variables, that is, liquidity, profitability, leverage, sales growth and size into the model could improve the model fit and show that the regression model is better than before or the hypothesized model fits with the data ( $\mathrm{H}_{0}$ is accepted).

\section{The Influence of Financial Ratios on Finan- cial Distress}

It can be seen from Table 3 that profitability and leverage have significantly influenced the financial distress. These results are in line with the expectation. PROF, as a proxy of profitability measured by ROI, is a signal for investors concerning the ability of firm's assets to produce net profits. The negative sign of profitability result (coefficient =22.629; $\mathrm{p}$-value $=0.020$ ) means that there is a disparity relationship between ROI and financial distress. The increase in ROI leads to a decrease in financial distress. This result is consistent with the study of [22], [23], [31], [33]. Turning to LEVE variable representing leverage measured by debt to equity ratio (DER), as expected, the sign is positive (coefficient $=1.542 ; \mathrm{p}$-value $=0.000$ ). This result is suggesting that the higher the leverage, the higher the firm's potentiality to go in the state of distress. The high ratio of leverage is signaling to investors that the firms could not efficiently manage their debts, thus increasing the firm's occurrence of financial distress. The study of [15] supports this finding.

In contrast, predictors LIKU, PPEN, KAPO, and UKUR are insignificant to financial distress. LIKU is liquidity proxied by the current ratio, the comparison between current assets and current liabilities. While the insignificant finding (coefficient $=0.070 ; p$-value $=0.672$ ) is in line with the study of [27], it is in contrast with the study of [21] and [35]. The low value of liquidity does not mean that the firm is experiencing financial distress, as the type of industry influences the value [6]. It does not detain investors from investing their funds since they still believe that the firm is the potential to grow [6].

Further, PPEN as the representation of sales growth results in negative sign and insignificant (coefficient $=0.554 ; p$-value $=0.600$ ). This result is in contrast with prediction. While this finding supports prior study [14], it does not support the studies of [31]. Experience in sales decreasing does not in line with the state of financial distress. Firms might keep in existence through their subsidiary's revenue or investment from investors; thus, they have the opportunity to increase sales through a previously prepared program by the marketing team or product diversification. KAPO that represents operating capacity measured by total asset turnover results in negative sign and insignificant (coefficient $=0.554$; p-value $=0.365$ ) as well. This finding supports the study of [22] and in contrast with the findings of [11] and [32]. Operating capacity or activity ratio that is low does not imply that a firm in the condition of distress. The increase of asset value followed by stagnant sales due to a sluggish stream of the economy, for example, might cause the low level of this ratio. However, as the company still can produce a positive profit, it means that the company is far from financial distress condition. Finally, the UKUR variable as a proxy for company size has a positive sign though it is insignificant (coefficient $=0.232 ; \mathrm{p}$-value $=0.489$ ) suggesting that the bigger company the higher its potential to carry 
out the activity as well as continue to innovate new products to attract market or do a business expansion. This result is not consistent with studies of [31] and [33].

\section{CONCLUSION}

This study has empirically examined the relationship between financial ratios and financial distress using data from the retail industry listed in the Indonesian capital market over the period 20142018. By using logistic regression, it can be concluded that probability and leverage are significant to explain the financial distress of the retail industry in Indonesia. In contrast, liquidity, sales growth, operating capacity, asset turnover, and size have no relationship with financial distress.

The findings of the study can have practical implications for entrepreneurs who run their retail business as well as investors, financial managers, and analysts. Provided that this study limits the data for the retail industry only, it is suggested that in the future, researchers use data from various industries and use of various models such as Zmijewski, Fulmer, Blasztk, CA-Score, and Springate to provide robustness in generalization and comparison, respectively.

\section{REFERENCES}

[1] Altman, Edward I. (1968). "Financial Ratios, Discriminant Analysis and the Prediction of Corporate Bankruptcy." The British Journal of Finance, XXII(4), 589-609.

[2] Anggraini, Dewi. (2016). "Financial Distress Model Prediction for Indonesian Companies." International Journal of Management and Administrative Sciences, 3(4), 74-84.

[3] Beaver, William H. (1966). "Financial Ratios as Predictors of Failure." Journal of Accounting Research, 4, 71-111. https://doi.org/10.2307/ 2490171.

[4] Blum, Marc. (1974). "Failing Company Discriminant Analysis". Journal of Accounting Research, 12(1), 1-25. https://doi.org/10.2307/ 2490525.

[5] Cultrera, Loredana, and Xavier Brédart. (2016). "Bankruptcy Prediction: The Case of Belgian SMEs." Review of Accounting and Finance, 15(1), 101-119. https://doi.org/10.1 108/RAF-06-2014-0059.

[6] Curry, Khirstina, and Erliana Banjarnahor. (2018). "Financial Distress Pada Perusahaan Sektor Properti Go Public Di Indonesia." In Seminar Nasional Pakar Ke 1, 207-221.

[7] Fatmawati, Mila. (2012). "Penggunaan the Zmijewski Model, the Altman Model, Dan the Springate Model Sebagai Prediktor Delisting." Jurnal Keuangan Dan Perbankan 16(1), 5665.
[8] Hemmert, Giselmar A. J., Laura M. Schons, Jan Wieseke, and Heiko Schimmelpfennig. (2018). "Log-Likelihood-Based Pseudo-R2 in Logistic Regression: Deriving Sample-Sensitive Benchmarks." Sociological Methods \& Research, 47(3), 507-531. https://doi.org/ https:// doi.org/10.1177/0049124116638107.

[9] Heniwati, Elok. (2019). "Studi Empiris Kekuatan Stabilitas Keuangan Perbankan Syariah Di Indonesia." Jurnal Ekonomi Bisnis Dan Kewirausahaan, 8(2): 147-160. https://doi. org/10.26418/jebik.v8i2.28015.

[10] Jensen, Michael C, and William H Meckling. (1976). "Theory of the Firm: Managerial Behavior, Agency Costs and Ownership Structure. J. Fin. Econ. 3, 162-176.

[11] Jiming, Li, and Du Weiwei. (2011). "An Empirical Study on the Corporate Financial Distress Prediction Based on Logistic Model: Evidence from China's Manufacturing Industry." International Journal of Digital Content Technology and Its Applications, 5(6), 368-379. https://doi. org/10.4156/jdcta.vol5.issue6.44.

[12] Lai, Hui Yin, Abdul Rashid Abdul Azis, and Toong Khuan Chan. (2014). "Effect of the Global Financial Crisis on the Financial Performance of Public Listed Construction Companies in Malaysia." Journal of Financial Management of Property and Construction, 19(3), 246-263. https://doi.org/10.1108/JFM PC-02-2014-0002.

[13] Lawrence, Kenneth D., Dinesh R. Pai, and Gary Kleinman. (2015). "Bankruptcy Prediction in Retail Industry Using Logistic Regression." Financial Modeling and Data Envelopment Applications, 13, 61-69. https://doi.org/ 10.1108/S0276-8976(2009)0000013006.

[14] Lisiantara, G. Anggana, and Lilik Febrina. (2018). "Growth Sebagai Preditor Financial Distress (Studi Empiris Pada Perusahaan Manufaktur Yang Terdaftar Di Bursa Efek Indonesia Tahun 2013-2016)." Prosiding SENDI, 978-979.

[15] Masdupi, Erni, Abel Tasman, and Atri Davista. (2018). "The Influence of Liquidity, Leverage and Profitability on Financial Distress of Listed Manufacturing Companies in Indonesia." Advances in Economics, Business and Management Research, 7, 223-228. https://doi. org/10.2991/piceeba-18.2018.51.

[16] Maulidina, Dara. (2014). "Faktor-Faktor Yang Mempengaruhi Financial Distress Pada Perusahaan Manufaktur Yang Terdaftar Di Bei." Media Riset Akuntansi, Auditing \& Informasi, 14(3), 89-106.

[17] Murtadha, Milla Alsura, Murtadha, Milla Alsura, Muhammad Arfan, and Mulia 
Saputra. (2018). "Factors Influencing Financial Distress and Its Impact on Company Values of the Sub-Sectors Firms in Indonesian.” Journal of Accounting Research, Organization and Economics, 1(2), 191-204. https://doi. org/10.24815/jaroe.v1i2.11883.

[18] Ohlson, James A. (1980). "Financial Ratios and the Probabilistic Prediction of Bankruptcy." Journal of Accounting Research, 18(1), 109. https://doi.org/10.2307/2490395.

[19] Panggabean, Martin, and Stefan Batara Panggabean. (2019). "Key Determinants of Indonesia's Banks Financial Performance." Jurnal Akuntansi Dan Keuangan, 21(2), 58-67. https://doi.org/10.9744/jak.21.2.58-67.

[20] Platt, Harlan D., and Marjorie B. Platt. (2002). "Predicting Corporate Financial Distress: Reflections on Choice-Based Sample Bias." Journal of Economics and Finance, 26(2), 184199. https://doi.org/10.1007/bf02755985.

[21] Prastiwi, Bela Indah and Rosiyana Dewi. (2019). 'Pengaruh Managerial Agency Cost Terhadap Financial Distress Dengan Struktur Kepemilikan Sebagai Variabel Pemoderasi." Jurnal Informasi, Akuntansi dan Keuangan Publik, 14(1), 81-104. https://dx.doi.org/10. 25105/jipak.v14i1.5016

[22] Restianti, Tya, and Linda Agustina. (2018). "The Effect of Financial Ratios on Financial Distress Conditions in Sub Industrial Sector Company." Accounting Analysis Journal, 7(1), 25-33. https://doi.org/10.15294/aaj.v5i3.18996.

[23] Rianti, Inten Puji, and Wiwin Yadiati. (2018). "The Influence Firm Size on Financial Distress: A Research on Agricultural Companies Listed in Indonesia Stock Exchange." International Business Management.

[24] Ross, Stephen A. (1977). "Determination of Financial Structure: The Incentive-Signalling Approach." The British Journal of Economics, 8(1), 23-40. https://doi.org/10.2469/dig.v27.n1.2.

[25] Savitha, Basri, and Naveen Kumar K. (2016). "Non-Performance of Financial Contracts in Agricultural Lending: A Case Study from Karnataka, India." Agricultural Finance Review, 76(3), 362-377. https://doi.org/10.1108/AFR01-2016-0001.
[26] Sayari, Naz, and Can Simga Mugan. (2017). "Industry Specific Financial Distress Modeling". BRQ Business Research Quarterly, 20, 4562. https://creativecommons.org/licenses/by-nc. $\mathrm{nd} / 4.0 /$

[27] Shaari, Noor Azizah, Nurfadhilah Abu Hasan, Yamuna Rani Palanimally, Kumar Moona, and Haji Mohamed. (2013). "The Determinants of Derivative Usage: A Study on Malaysian Firms." Journal of Contemporary Research in Business, 5(2), 300-316.

[28] Shahid, Muhammad Ali, and Zaheer Abbas. (2012). "Financial Stability of Islamic Banking in Pakistan: An Empirical Study." African Journal of Business Management, 6(10), 37063714. https://doi.org/10.5897/ajbm11.1306.

[29] Spence, Michael. (1973). "Job Market Signaling." The Quarterly Journal of Economics, 87(3), 355-374.

[30] Succurro, Marianna, Giuseppe Arcuri, and Giuseppina Damiana Costanzo. (2019). "A Combined Approach Based on Robust PCA to Improve Bankruptcy Forecasting." Review of Accounting and Finance, 18(2), 296-320. https://doi.org/10.1108/RAF-04-2018-0077.

[31] Thim, Chan Kok, Yap Voon Choong, and Chai Shin Nee. (2011). "Factors Affecting Financial Distress: The Case of Malaysian Public Listed Firms." Corporate Ownership and Control, 8(4D), 345-351. https://doi.org/10.22495/cocv 8 i4c3art3.

[32] Widhiari, Ni Luh Made Ayu, and Ni K. Lely Aryani Merkusiwati. (2015). "Pengaruh Rasio Likuiditas, Leverage, Operating Capacity, Dan Sales Growth Terhadap Financial Distress." $E$ Jurnal Akuntansi, 11(2), 456-469.

[33] Zhafirah, Anindya, and Majidah. (2019). "Analisis Determinan Financial Distress (Studi Empiris Pada Perusahaan Subsektor Tekstil Dan Garmen Periode 2013-2017)." Jurnal Riset Akuntansi Dan Keuangan, 7(1), 195202. https://doi.org/10.17509/jrak.v7i1.15497.

[34] Zmijewski, Mark E. (1984). "Methodological Issues Related to the Estimation of Financial Distress Prediction Models." Journal of Accounting Research, 22, 59-82. https://doi.org/ 10.2307/2490859. 